\title{
Accuracy assessment for detection of leafy spurge with hyperspectral imagery
}

\author{
AMY E. PARKER WILLIAMS AND E. RAYMOND HUNT, JR.
}

Authors are Research Associate, Department of Botany, University of Wyoming, PO Box 3165, Laramie, Wyo. 82071-3165; and Research Physical Scientist, USDA ARS Hydrology and Remote Sensing Laboratory, Building 007 Room 104, 10300 Baltimore Ave., Beltsville, Md. 20705-2350. At the start of this research, Parker Williams was a Graduate Student and Hunt was an Assistant Professor at the Department of Botany, University of Wyoming, Laramie, Wyo. 82071 .

\section{Abstract}

When flowering, leafy spurge (Euphorbia esula L.) has conspicuous yellow-green bracts that are spectrally distinct from other vegetation and may be distinguished with hyperspectral remote sensing. In July 1999, Airborne Visible Infrared Imaging Spectrometer (AVIRIS) data were acquired in northeastern Wyoming, near Devils Tower National Monument. Using the reflectance spectrum of flowering leafy spurge, leafy spurge occurrence was determined using a new method of spectral mixture analysis, Mixture Tuned Matched Filtering (MTMF). Ground reference data (146 sites) were obtained 2 weeks before and after AVIRIS overflight to test the classification accuracy of leafy spurge. For 3 land cover types: mixed prairie, riparian, and coniferous woodlands, the presence or absence leafy spurge was detected with an overall accuracy of $95 \%$ using a 0.10 threshold for detection. Differences in classification thresholds resulted in a trade-off between false positives, pixels that were mapped as leafy spurge but did not contain leafy spurge on the ground, and false negatives, areas that had leafy spurge on the ground but were not mapped as leafy spurge. Detection of leafy spurge occurrence was best for mixed prairie and riparian cover types, and somewhat less successful for conifer woodlands because of interference from tree crowns and their shadows. The advantage of the MTMF technique is it allows automated processing of hyperspectral imagery to generate accurate maps of leafy spurge occurrence.

Key Words: Euphorbia esula L., remote sensing, spectral mixture analysis, classification accuracy, AVIRIS

Leafy spurge (Euphorbia esula L., sensu lato) is a noxious perennial weed that infests approximately 1.2 million hectares of land in North America (Lajeuness et al. 1999) and causes severe economic impact (Leitch et al. 1996). Anderson et al. (2003) conclude that biologically-based control of leafy spurge is now practical. One of the remaining research needs in leafy spurge management, and in weed management as a whole, is the adequate,

\footnotetext{
Hunt, corresponding author, email: erhunt@hydrolab.arsusda.gov

The authors thank Dr. Diane E. Wickland (NASA) for supporting the AVIRIS data acquisition, and Dr. Gerald L. Anderson (USDA ARS) of TEAM Leafy Spurge and the Wyoming Space Grant Consortium for funding. Also, the authors thank Dr. David J. Kazmer (USDA ARS) and Dr. Ronald W. Marrs and Dr. Stephen T. Jackson (University of Wyoming) for discussions.

Manuscript accepted 28 Mar. 03.
}

\section{Resumen}

Cuando esta en floración, el "Leafy spurge" (Euphorbia esula L.) tiene brácteas amarillo-verdes sobresalientes que son espectralmente distintas a la otra vegetación y pueden ser distinguidas con sensores remotos hiperespectrales. En Julio de 1999 se adquirieron datos de espectrometría de imágenes infrarrojas aéreas visibles (AVIRIS) del nordeste de Wyoming, cerca del Monumento Nacional Devils Tower. Usando el espectro de reflectancia de la floración del "Leafy spurge" se determinó su ocurrencia mediante un nuevo método de análisis de mezcla espectral, Filtrado de mezcla aparejada sintonizada (MTMF). Dos semanas antes y dos después de vuelo del AVIRIS se obtuvieron datos en tierra (en 146 sitios) para probar la certeza de la clasificación del "Leafy spurge". Para 3 tipos de cobertura, pradera mixta, ribereña y bosques de coníferas, la presencia o ausencia de 'Leafy spurge"se detectó con una certeza general del $95 \%$, usando un umbral de detección de 0.10 . Diferencias en los umbrales de clasificación resultaron en un sacrificio entre falsos positivos, pixeles que fueron mapeados como "Leafy spurge" pero no contenían la especie en tierra y falsos negativos, áreas que tenían "Leafy spurge" en tierra pero no fueron mapeados como "Leafy spurge". La detección de la ocurrencia de "Leafy spurge" fue mejor para los tipos de cobertura de pradera mixta y ribereña y algo menos exitosa para los bosques de coníferas, debido a la interfase entre las copas de los árboles y sus sombras. La ventaja de la técnica MTMF es que permite el procesamiento automático de imágenes hiperespectrales para generar mapas certeros de la ocurrencia de "Leafy spurge".

cost-effective, large-scale, and long-term mapping and monitoring of plant populations (Johnson 1999, Anderson et al. 2003). Ground survey work over large areas is prohibitively expensive and time-consuming (Everitt et al. 1995). Remote sensing images depicting the presence or absence of leafy spurge can assist land managers in identifying and prioritizing areas for the different tools of integrated pest management (Anderson et al. 2003).

Remote sensing is a set of techniques that can contribute significantly to rangeland management (Tueller 1989, 1995), and weed management on rangelands (Everitt et al. 2001, Hunt et al. 2003). Leafy spurge is a good candidate for detection by remote sensing because the conspicuous yellow-green flowering bracts are spectrally unique when compared to other, co-occurring vegetation (Everitt et al. 1995, Anderson et al. 1999, Parker Williams and Hunt 2002). High-spectral-resolution imagery, also called imag- 
ing spectroscopy or hyperspectral remote sensing, may be the most appropriate data for mapping individual plant species with a accuracy and precision (Clark et al. 1995). With hyperspectral data, a relatively new technique of spectral mixture analysis, Mixture Tuned Matched Filtering (MTMF), can be used to detect the occurrence of spectrally-unique materials (Boardman 1998, RSI 1999).

Parker Williams and Hunt (2002) used the MTMF technique with Airborne Visible Infrared Imaging Spectrometer (AVIRIS) imagery to estimate amounts of leafy spurge cover; however the analyses suggested there will be problems detecting leafy spurge at low cover. Because the MTMF technique uses an arbitrary threshold value of abundance, areas with some leafy spurge may be erroneously classified as "leafy spurge not present" (false negative error or error of omission). On the other hand, areas without leafy spurge may be erroneously classified as "leafy spurge present" (false positive error or error of commission). If maps of leafy spurge distribution from remotely-sensed images are to be useful for management, the classification accuracy must be determined with independent ground reference data. The objective of this study is to apply the standard methods of accuracy assessment in remote sensing (Stehman and Czaplewski 1998, Congalton and Green 1999) to a classification of leafy spurge occurrence (Parker Williams and Hunt 2002) with an independent ground data set. Because the rangeland landscape is comprised of a mosaic of land cover types, we assessed the accuracy of leafy spurge detection in 3 different plant communities: mixed grass prairie, riparian zones, and coniferous woodlands.

\section{Background}

\section{Accuracy Assessment}

Classification is the process of assigning variables into discrete categories of useful information. Landcover classification uses remotely-sensed reflectances or radiances to determine the category to which a given pixel belongs. However, errors of landcover classification occur, because of soil background differences, positional errors, landcover mixtures (mixed pixels), or human errors.

The most effective way to represent classification accuracy is via an error matrix (Jensen 1996, Stehman and Czaplewski 1998, Congalton and Green 1999). The class of a given unit on the ground is compared to the class of that unit from the remotely sensed image; correctly classified units would be shown on the major diagonal of the matrix. For each error matrix, overall accuracy, producer's accuracy, user's accuracy, errors of commission, and errors of omission can be calculated. Overall accuracy is simply the total number of units correctly classified divided by the total number of sample units examined in the error matrix.

An error of commission occurs when a unit is included into a category in which it does not belong (false positive). An error of omission occurs when a unit is not included in a category in which it does belong (false negative). Every error in the classification is an omission from the correct category and a commission to a wrong category. The producer's accuracy is a measure of the probability of a sample unit being correctly classified into a particular category, and is 1 minus the omission error. The user's accuracy is the probability that a sample unit classified on the map actually represents that category on the ground, and is 1 minus the commission error. It is standard practice in remote sensing to calculate the producer's and user's accuracies from an error matrix (Jensen 1996). In other disciplines, standard practices prefer the use of commission and omission error rates.

Two primary decisions must be made in designing an experiment to assess accuracy of a landcover classification (Stehman and Czaplewski 1998, Congalton and Green 1999), selection of the units for sampling, and determination of the unit areas in the image and on the ground for comparison. Sample unit selection must insure that representative categories on the landscape are used and that the sample units are widely distributed to avoid geospatial correlation. Generally, 50 sample units per class are sufficient for accuracy assessment (Jensen 1996, Congalton and Green 1999).

There is no single preferred method for selection of the image and ground areas for comparison (Congalton and Green 1999). Because a pixel in an image has an arbitrary location on the ground, and because positional errors of maps and global positioning system receivers become significant with small pixel sizes, areas based on geographic information system polygons are used frequently (Congalton and Green 1999). However, Jensen (1996) and Janssen and van der Wel (1994) suggest using individual pixels is appropriate if a per-pixel classification is assessed for accuracy, which avoids problems caused by generating "homogeneous" polygons on a landscape. It has been shown that pixel positional error results in conservative bias of the accuracy assessment (Verbyla and Hammond 1995); therefore, the unavoidable positional error introduced into this assessment would result in lower, or conservative, estimates of mapping accuracy.

\section{Spectral Mixture Analysis}

The reflectance spectrum for each pixel in a remotely sensed image is characteristic of the mixture of component materials on the ground. To analyze the mixtures and arrive at sub-pixel estimates of abundances, techniques of spectral mixture analysis are employed (Adams et al. 1995, Smith et al. 1990). In general, these techniques model each pixel spectrum as a linear combination of a finite number of spectrally distinct signatures or "endmembers." This is analogous to estimating soil texture, where the texture of a particular soil sample is a linear combination of 3 endmembers: sand, silt and clay. For most spectral mixture analysis methods, the reflectance spectrum for each endmember is a required input. The outputs from spectral mixture analysis are images of endmember abundance, from 0 to $100 \%$, which is related to the cover fraction of that pixel (Roberts et al. 1998, McGwire et al. 2000). In general, these techniques are potentially powerful for rangeland management, because the percent cover of vegetation, bare soil and litter can be derived for a given pixel from remotely sensed imagery.

Mixture Tuned Matched Filtering (MTMF) is a special type of spectral mixture analysis based on signal processing methodologies (Harsanyi and Chang 1994, Boardman et al. 1995, Boardman 1998, RSI 1999). It performs a partial unmixing by finding only the pixels where 1 userdefined endmember spectrum is statistically distinct from the average background spectrum. Simple matched filtering provides the abundance fraction of the chosen endmember, from 0 to $100 \%$. Usually simple matched filtering results in a large number of false-positive errors. Mixture tuning constrains the results of the matched filtering with an infeasibility score, to indicate the probability that the sum total of all abundance fractions equals 1 (Boardman 1998, RSI 1999). The exact mathematical formulation of MTMF is not required for its use with hyperspectral imagery.

The major practical advantage of MTMF over other techniques of spectral mixture 
analysis is it does not require that all image endmembers be identified (Boardman 1998, RSI 1999). Therefore, the reflectance spectra for the different soil types (surface moisture, specific minerals and overall textures affect the reflectance spectrum), roofing materials, road surfaces, water bodies, and other natural and man-made features do not have to be identified either from pure pixels in an image or from the ground using a field spectroradiometer. Thus, MTMF may be the ideal technique for detecting the abundance of a single endmember, leafy spurge.

\section{Materials and Methods}

\section{Study Area}

The study area for this research is in Crook County in northeastern Wyoming. It consists of an approximately $65 \mathrm{~km}^{2}$ area including Devils Tower $\mathrm{National}$ Monument (about $44^{\circ} 35^{\prime} \mathrm{N} 104^{\circ} 45^{\prime} \mathrm{W}$ ). The remainder of the study area is composed of private lands that are used extensively for livestock grazing (cattle and sheep) with some areas of dryland farming and hay production. Elevations in the study area range from $1219 \mathrm{~m}$ along the Belle Fourche River to $1584 \mathrm{~m}$ at Missouri Buttes along the northern border of the study area. The average annual precipitation is $440 \mathrm{~mm}$.

The vegetation of the study area is primarily a mosaic of 3 land cover types. The first is conifer woodlands, which are comprised of ponderosa pine (Pinus ponderosa P. \& C. Lawson) and juniper (Juniperus scopulorum Sarg.) occurring on a plateau of sedimentary rocks. The second land cover type is the riparian zones and draws, which are characterized by willow (Salix spp.), plains cottonwood (Populus deltoides Bartr. ex Marsh.), bur oak (Quercus macrocarpa Michx.), and green ash (Fraxinus pennsylvanica Marsh.). The third land cover type is a northern mixed grass prairie composed of grasses, forbs, and sagebrush species. Leafy spurge is very well established throughout the study area.

\section{Hyperspectral Image Analysis}

Airborne Visible Infrared Imaging Spectrometer (AVIRIS) data were acquired over the study area on 6 Jul. 1999 by the National Aeronautics and Space Administration's Jet Propulsion Laboratory (Pasadena, Calif.). The AVIRIS sensor has 224 contiguous bands from about 400 to $2500 \mathrm{~nm}$ wavelength; each band is about $10 \mathrm{~nm}$ wide (Green et al. 1998). The sensor was flown on an ER-
2 aircraft at an altitude of $20 \mathrm{~km}$, resulting in a pixel size of $20 \mathrm{~m}$ by $20 \mathrm{~m}$. Two AVIRIS scenes, each approximately $11 \mathrm{~km}$ by $9 \mathrm{~km}$, covered much of the study area.

The AVIRIS scenes were radiometrically corrected by the Jet Propulsion Laboratory (Green et al. 1998). The data were corrected from radiance to apparent surface reflectance using the Atmosphere Removal Program version 3.1 (Gao et al. 1993, 1999). Because the wavelengths from 400 to $1000 \mathrm{~nm}$ contained the spectral information for distinguishing leafy spurge from other vegetation, we used bands 6 through 68 for all analyses.

The atmospherically corrected data were entered into the Minimum Noise Fraction routine from the Environment for Visualizing Images (ENVI), version 3.2, distributed by Research Systems, Inc. (RSI, Boulder, Colo.). This routine essentially performs 2 principal components transformations to reduce the computational load (RSI 1999). The transformed data were entered into the Pixel Purity Index routine to determine the pixels that are spectrally extreme; spectrally extreme pixels are often the spectral endmembers (RSI 1999). We identified the most pure pixels for leafy spurge in the images and used the pixel-average reflectance spectrum for the leafy spurge endmember.

We used the Mixture Tuned Matched Filtering (MTMF) routine from ENVI (RSI 1999). Based on 2 criteria, each pixel in the MTMF result image was classified as either leafy spurge present or leafy spurge absent. Based on results presented in this study, all pixels with a MTMF fraction greater than 0.10 and an infeasibility score less than 6.00 were classified as leafy spurge present. Because there is a tradeoff between errors of omission and commission for overall accuracy, we also classified the AVIRIS image using MTMF threshold values of 0.05 and 0.20 .

\section{Accuracy Assessment Procedures}

To ensure that the various habitats in which leafy spurge occurred were included in the selection of ground reference sites and that the sampling sites were well distributed geographically, a Landsat 5 Thematic Mapper (14 June 1991) was used to perform an initial land-cover classification of the study area to locate 3 land-cover types (prairie, riparian, and conifer woodland). Eighty-five points were randomly selected within each cover type, resulting in a total of 255 ground reference sites. To minimize errors due to changes in leafy spurge cover and distribution, ground reference sites were visited within a time frame of 2 weeks before and 2 weeks after the AVIRIS data acquisition. Within this time frame, 246 of the selected locations were visited on the ground; however, only 146 of these sites fell within the 2 AVIRIS scenes.

The sample unit of an image pixel $(20 \mathrm{~m}$ by $20 \mathrm{~m}$ ) was used in combination with a slightly larger area for the ground reference site $(50 \mathrm{~m}$ by $50 \mathrm{~m})$. The center of each ground reference site was located on the AVIRIS image using an U.S. Geological Survey orthophoto quad and a selective availability encoded Rockwell Precision Federal Global Positioning System unit (Rockwell International Corporation, Cedar Rapids, Iowa). The estimated error associated with locating the ground reference site on the AVIRIS image was approximately 1 pixel, which is similar to what other researchers have reported (Hall et al. 1998, Marsh et al. 1994). The larger area on the ground $\left(2500 \mathrm{~m}^{2}\right)$ aided the classification by incorporating the positional error from image registration.

\section{Ground Reference Data Collection}

At each ground reference site, the primary land cover type (prairie, riparian, or conifer woodland) was determined. Transects were established from the center to the edge of each ground reference site in 4 directions. The first transect was randomly determined and then each additional transect was located at $90^{\circ}, 180^{\circ}$, and $270^{\circ}$ from the first. The primary (most abundant) landcover type was determined by walking the 4 transects and making a visual estimate. If present, a secondary landcover type was determined visually.

Leafy spurge occurrence (presence or absence) was determined visually while walking the 4 transects. Separate tallies were made if leafy spurge occurred in the primary land cover type and if leafy spurge occurred anywhere at the ground reference site. Because the sites were initially selected on the basis of a Landsat classification, and because the accuracy assessment required only occurrence data, quantitative estimates of leafy spurge cover were not made for this experiment. A map of each site was sketched to scale, documenting the distribution of the primary and secondary cover types and the distribution of leafy spurge in the plot.

\section{Spectral reflectance data}

Reflectance spectra were acquired in the field in June 1999, before the AVIRIS flight, using an Analytical Spectral Devices, Inc. (Boulder, Colo.) Fieldspec 
UV/VNIR Spectroradiometer. This instrument measures spectral radiant flux densities from 350 to $1050 \mathrm{~nm}$ wavelength. All measurements were made with the bare optic tip at a height of $1.3 \mathrm{~m}$ above the ground, resulting in a field-of-view diameter of about $0.5 \mathrm{~m}$. About every 2 to 3 minutes, measurements were made of a white reference panel (Spectralon); spectral reflectances were calculated from the ratio of the target data to the white panel reading. These data were used to verify identification of the spectral endmembers of leafy spurge.

\section{Results and Discussion}

The flowering shoots of leafy spurge have much higher reflectance from 525 to $650 \mathrm{~nm}$ and from 750 to $900 \mathrm{~nm}$ wavelength compared to non-flowering shoots of leafy spurge, shoots of curly dock (Rumex crispus L.) and clumps of grass (Fig. 1). The higher reflectance of flowering leafy spurge shoots in the green $(500-550 \mathrm{~nm})$ and yellow $(550-600 \mathrm{~nm})$ portions of the spectrum $(500-600 \mathrm{~nm})$ is expected because its visual conspicuousness. The higher near-infrared (750-900 $\mathrm{nm}$ ) reflectance of flowering leafy spurge may be an effect of sample selection; nearinfrared reflectance usually increases with increasing plant density (Tueller 1989, Everitt et al. 1995). Another reason for the high near-infrared reflectance is that leafy spurge is a dicot; the other dicot, curly dock, also has a high near-infrared reflectance compared to native grasses. Because flowering leafy spurge shoots have the same reflectances in the violetblue (400-500 $\mathrm{nm}$ ) and orange-red $(600-700 \mathrm{~nm})$ portions of the spectrum (Fig. 1), the increased reflectance in the yellow-green and near-infrared was not

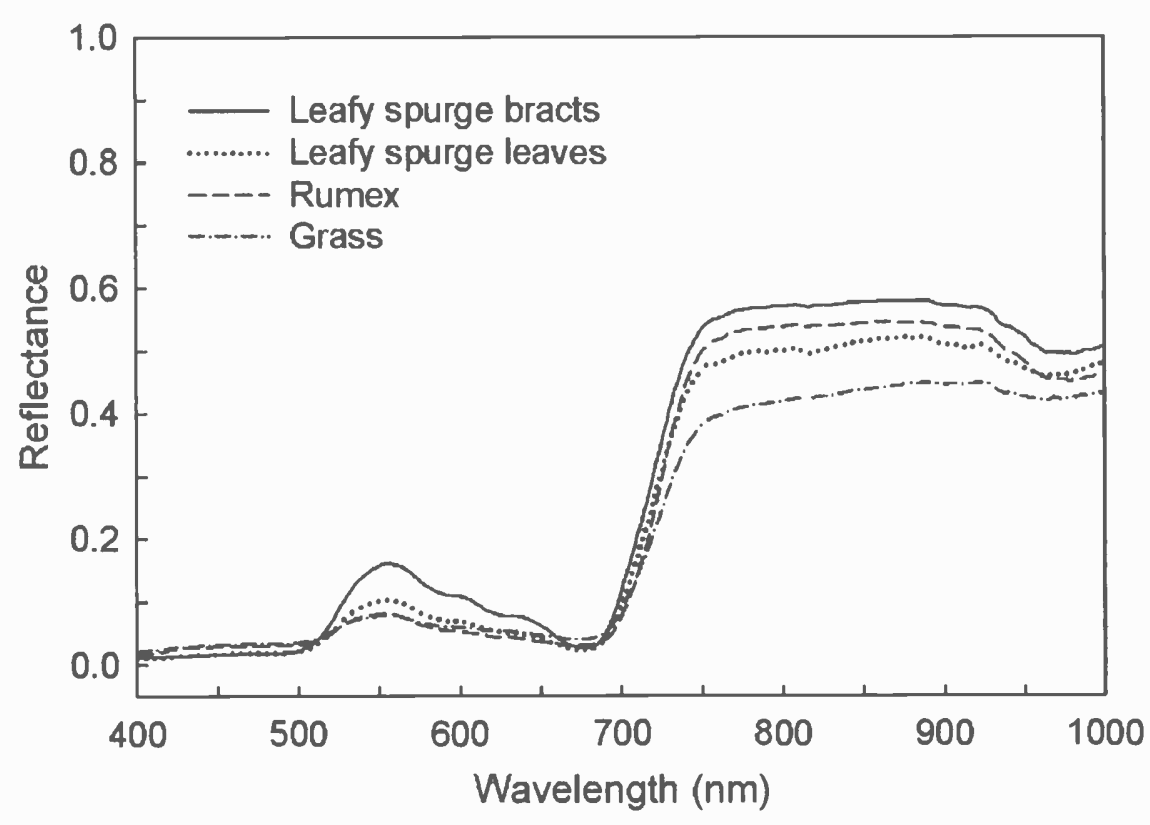

Fig. 1. Reflectance spectra of flowering shoots of leafy spurge, non-flowering shoots of leafy spurge, shoots of curly dock (Rumex crispus L.), and a mixture of native grasses.

the result of a wavelength-independent increase in brightness. Thus, the portion of the spectrum that uniquely identifies flowering leafy spurge is the yellow-green.

Figure 2 shows the average of green, red, and near-infrared pixel reflectances in a gray-scale image centered around Devils Tower National Monument in order to locate areas of leafy spurge occurrence. Figure 3 shows the Mixture Tuned Matched Filter (MTMF) abundances. Much, but not all, of the leafy spurge in the study area is located along the Bell Fourche River and its tributaries (Fig. 2). These are the areas with very high values of MTMF abundance (Fig. 3). Using a false color composite of a green band, a red band and a near-infrared band, areas of leafy spurge along the Bell Fourche River are bright orange, showing the contribution of the yellow-green flowering bracts to the red and green bands. However, there are many pixels in the left half of the image that were predicted to have leafy spurge present (Fig. 3). These areas are in woodlands or in rugged terrain, where visual inspection of AVIRIS image did not detect leafy spurge infestation. It is not known if high-spatial-resolution, colorinfrared photographs could be used to detect spurge in these wooded areas.

From Parker Williams and Hunt (2002), the slope between MTMF abundance and leafy spurge cover was significantly less than unity $(0.745 \pm 0.0622)$ and the intercept was significantly greater than zero $(0.0727 \pm 0.0267)$ for a combined regression with all cover types. The positive

Table 1. Error matrix of leafy spurge occurrence (presence or absence) in the primary land cover type. The threshold value of Mixed Tuned Matched Filtering (MTMF) abundance was $\mathbf{0 . 1 0}$, below which leafy spurge is classified as absent on the image. A remotely-sensed pixel may be comprised of a mixture of land cover types, the primary land cover type dominates the spectral reflectance of that pixel. Leafy spurge is classified as present on the ground if it occurs only in the primary land cover type of a given pixel.

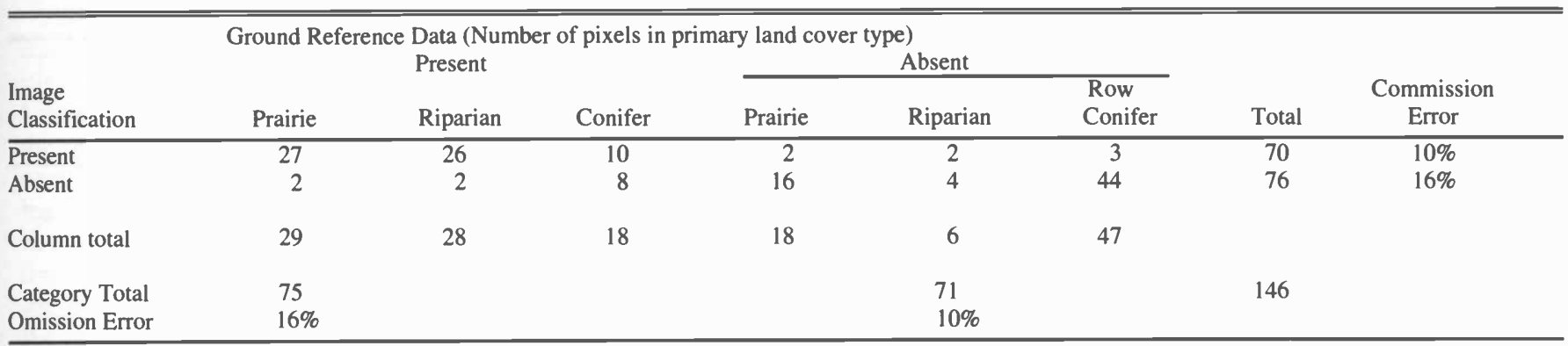

Correctly Classified $=127$

Overall Accuracy $=86.99$ 


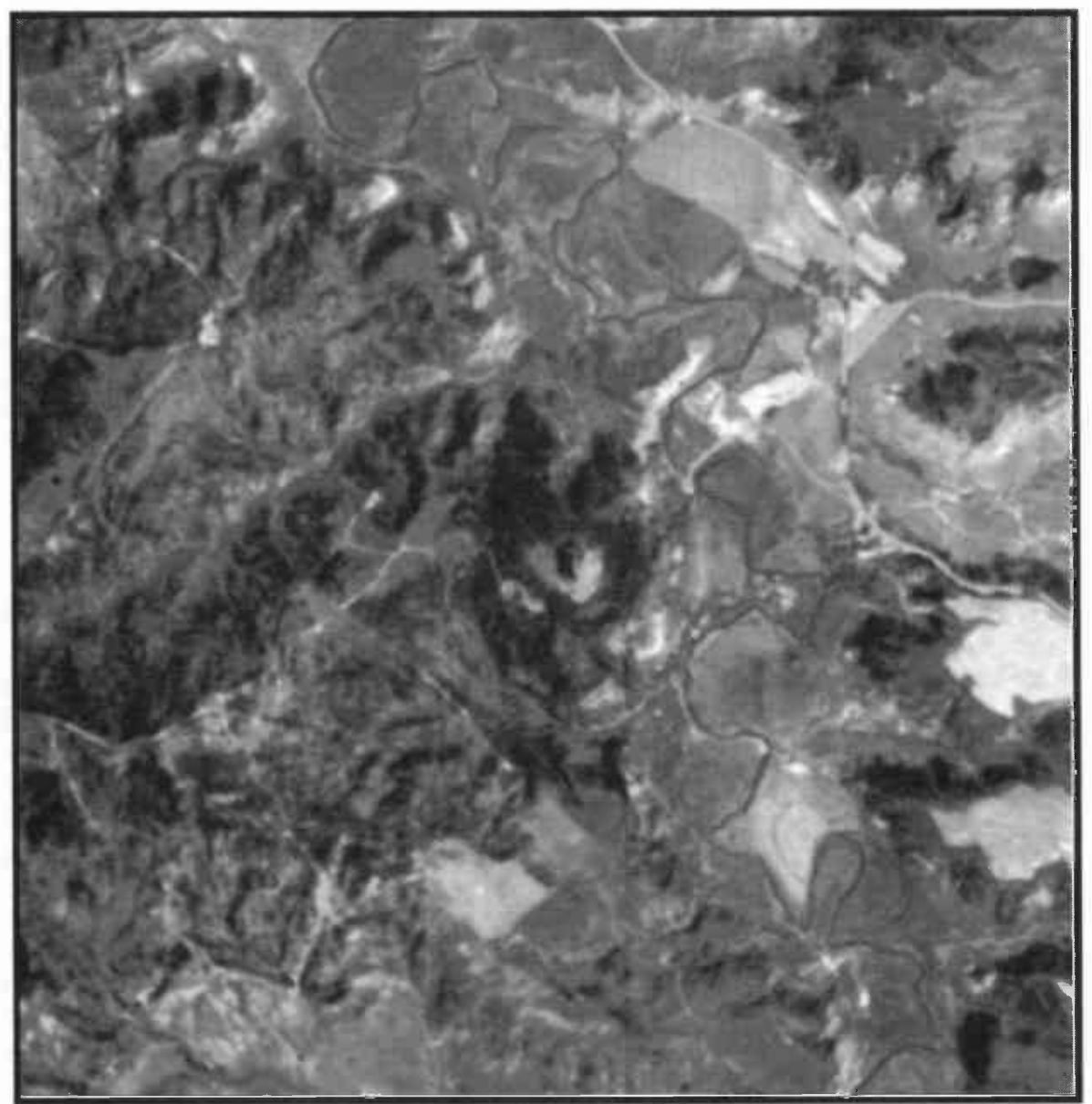

Fig. 2. Airborne Visible Infrared Imaging Spectrometer (AVIRIS) image with Devils Tower National Monument in the center. The upper left corner of the image points north. The grayscale values are the averages of bands 23 (green), 33 (red) and 53 (near-infrared), which shows the Bell Fourche river and coniferous woodlands as dark gray, prairie as medium gray, and rocks, bare soil, and agricultural fields as light gray.

intercept of the regression equation indicates there may be some pixels that have no flowering leafy spurge, but the abundance value may indicate its presence, which is a false-positive error or an error of commission. The manual (RSI 1999) recommends a threshold of 0.10 as a good compromise between errors of omission cover type was $86.99 \%$ (Table 1). The primary cover type dominates the pixel reflectance, and detection of leafy spurge in the primary land cover type is important for comparison of MTMF with other methods of classification accuracy assessment (Hunt et al. 2003). Furthermore, because the amount of the primary land cover type is greater, the amount of spurge is expected to be greater, hence it should be easier to detect leafy spurge occurrence.

A pixel on the map classified as leafy spurge was leafy spurge on the ground $90 \%$ of the time (user's accuracy); and $84 \%$ of the time, the AVIRIS data correctly mapped areas that were leafy spurge on the ground (producer's accuracy). The errors of omission and commission for the absence of leafy spurge were $10 \%$ and 16 $\%$, respectively (Table 1 ). The majority of classification errors occurred when the AVIRIS data failed to detect and map some areas of leafy spurge in the study area (false negatives). In contrast, far fewer sites were mapped as leafy spurge in the AVIRIS imagery that were not leafy spurge on the ground (false positives).

When examining the patterns of error among the different vegetation types, the highest number of classifications errors occurred in the conifer woodlands (Table 1). A total of 11 sites ( 8 false negatives and 3 false positives) were misclassified in this vegetation type as compared to 4 each for the riparian and prairie sites. Eight of 12 of the false negative errors occurred when the AVIRIS imagery failed to detect leafy spurge in conifer woodland on the ground (Table 1). This was most likely due to the interference of the conifer tree canopy and resulting shadows cast by the tree crowns. However, the success of detecting spurge in the understory of conifer woodlands about half the time indicates that MTMF analyses are very promising.

Table 2. Error matrix of leafy spurge occurrence (presence or absence) in the image pixel. The threshold value of Mixed Tuned Matched Filtering (MTMF) abundance was $\mathbf{0 . 1 0}$, below which leafy spurge is classified as absent on the image. Leafy spurge is classified as present on the ground if it occurs anywhere in the remotely-sensed pixel.

\begin{tabular}{|c|c|c|c|c|c|c|c|c|}
\hline \multirow[b]{3}{*}{$\begin{array}{l}\text { Image } \\
\text { Classification }\end{array}$} & \multicolumn{8}{|c|}{ Ground Reference Data (Number of pixels in primary land cover type) } \\
\hline & & Present & & & Absent & & & \\
\hline & Prairie & Riparian & Conifer & Prairie & Riparian & $\begin{array}{l}\text { Row } \\
\text { Conifer }\end{array}$ & Total & $\begin{array}{c}\text { Commission } \\
\text { Error }\end{array}$ \\
\hline Present & 29 & 28 & 13 & 0 & 0 & 0 & 70 & $0 \%$ \\
\hline Absent & 2 & 1 & 4 & 16 & 5 & 48 & 76 & $9 \%$ \\
\hline Column total & 31 & 29 & 17 & 16 & 5 & 48 & & \\
\hline Category Total & & 77 & & & 69 & & 146 & \\
\hline Omission Error & & $9 \%$ & & & & $0 \%$ & & \\
\hline
\end{tabular}




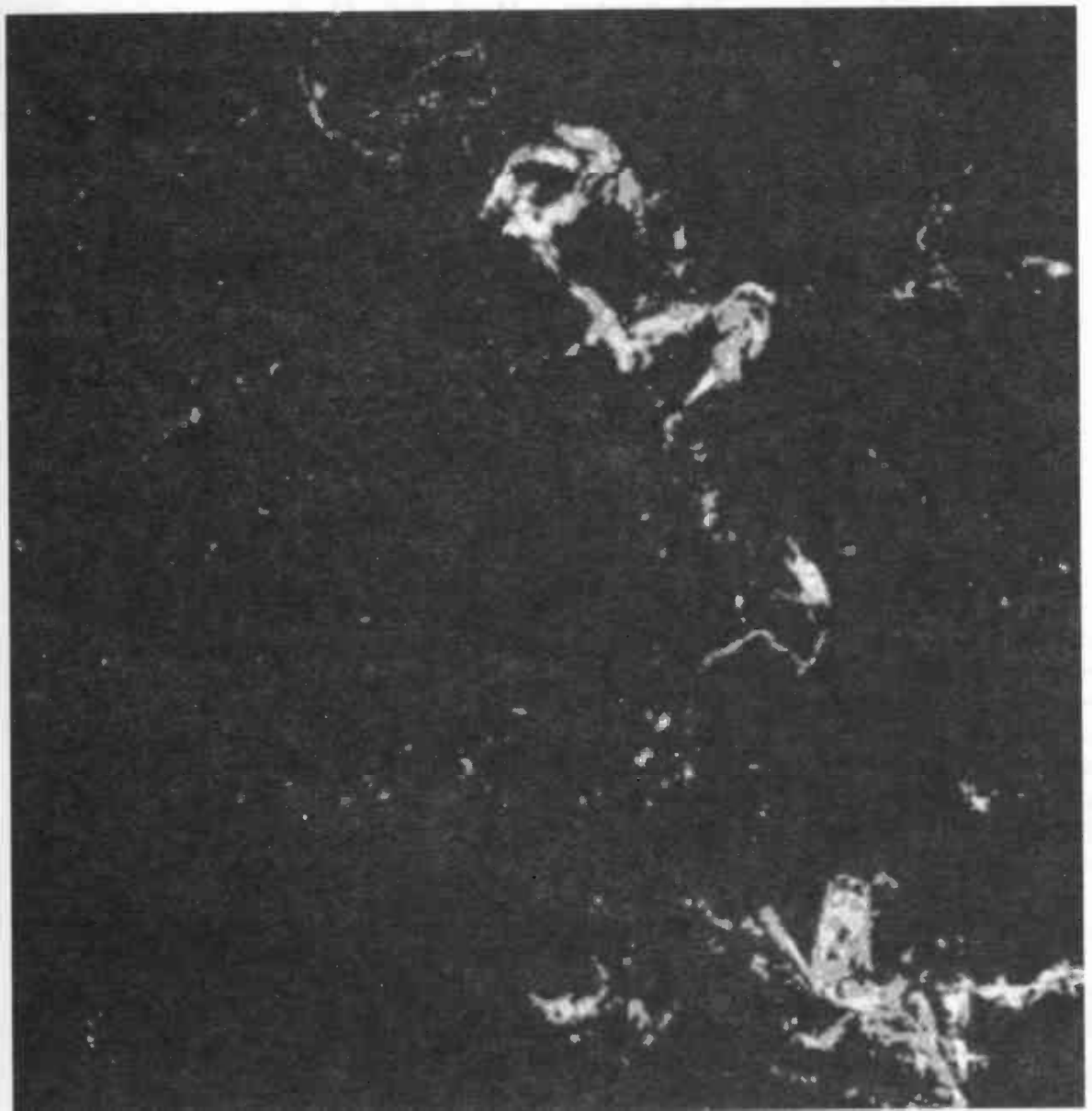

Fig. 3. Abundance image of leafy spurge from the Mixture Tuned Matched Filtering (MTMF) using the Airborne Visible Infrared Imaging Spectrometer (AVIRIS) image in Fig. 2. The grayscale image is black for areas with an abundance $=0.0$, bright white for areas with an abundance of 1.0, and linearly scaled for intermediate MTMF abundances. The classification threshold for detection of leafy spurge was set at 0.10 .

Remotely-sensed pixels generally represent a mixture of land cover types on the ground and the secondary land cover types can influence the pixel's reflectance spectrum. Table 2 presents the error matrix when leafy spurge was present anywhere in the pixel, not just in the primary land cover class. The overall accuracy increased to $95.21 \%$. The MTMF method failed to detect 7 sites where leafy spurge was present on the ground, but had no false positive errors (Table 2).

Adjustment of the threshold value is a trade-off between the number of false positives and the number of false negatives. Using a threshold value of 0.05 decreased the overall accuracy and the accuracy for each land cover type (Table 3) by increasing the number of false positives. Using a threshold value of 0.20 also decreased the overall accuracy (Table 3 ) by increasing the number of false negatives. Therefore, the recommended threshold value of 0.10 (RSI 1999) was indeed a good tradeoff between the number of false negative and false positive errors.

Leafy spurge was mapped with an overall accuracy ranging from $75 \%$ to $97 \%$ depending on the criteria employed (Table 3 ). Using a threshold value of 0.10 and neglecting land cover type as an important variable, the overall accuracy is $95 \%$ (Table 2). Overall accuracies for landcover classifications reported in the literature vary widely. Furthermore, there is no general consensus as to what level of accuracy is acceptable. In fact, the acceptable level of accuracy is a project-based decision that will vary depending on the end utilization of the derived map and the needs of the end user (Congalton and Green 1999). We achieved very high accuracies because we used a powerful new technique with one of the best airborne sensors available for a simple classification of leafy spurge occurrence. Most accuracy assessments are for classifying all land cover types, not just 1 or 2 . Furthermore, we achieved the very high accuracies because the timing of the AVIRIS overflight was near the peak of the flowering season for leafy spurge. Earlier or later overflights would have missed much of the leafy spurge because non-flowering leafy spurge has a similar spectrum as some other co-occurring vegetation (Fig. 1).

There are several characteristics of leafy spurge that make it an ideal species for detection from remotely sensed data; therefore caution must be fostered when considering mapping other invasive species using hyperspectral data. Leafy spurge grows in large dominant stands, is a robust plant with a dense canopy, and has an extended period of flowering. Obviously, there is difficulty in mapping any species under tree canopies using remote sensing. Although this is one limitation of the method, results demonstrated that leafy spurge growing in the understory of woodland areas was often detectable in the AVIRIS imagery. However, even with these limitations, hyperspectral remote sensing data and the MTMF technique provide an automated, accurate method of mapping leafy spurge over larger areas.

One of the most likely uses for a regional leafy spurge map would be to track changes in leafy spurge distribution over time due to population spread and control practices. With repeatable, consistent mapping methodology the level of accuracy attained in this study would provide very accurate representations of leafy spurge distribution. The increasing avail-

Table 3. Accuracy of leafy spurge detection (presence or absence) for the primary land cover type at different threshold values of Mixed Tuned Matched Filtering (MTMF) abundance. Below the threshold MTMF value, leafy spurge is classified as absent.

\begin{tabular}{llcccc}
\hline \hline MTMF & Ground & \multicolumn{3}{c}{ Primary Land Cover Type } \\
Threshold & Classification & Prairie & Riparian & Conifer & Overall \\
\hline 0.05 & $1^{\circ}$ land cover & 0.830 & 0.794 & 0.754 & 0.788 \\
0.05 & pixel & 0.894 & 0.912 & 0.877 & 0.890 \\
0.10 & $1^{\circ}$ land cover & 0.915 & 0.882 & 0.831 & 0.870 \\
0.10 & pixel & 0.957 & 0.971 & 0.938 & 0.952 \\
0.20 & $1^{\circ}$ land cover & 0.851 & 0.853 & 0.831 & 0.842 \\
0.20 & pixel & 0.915 & 0.941 & 0.923 & 0.925 \\
\hline
\end{tabular}


ability of other airborne sensors, such as the Compact Airborne Spectrographic Imager and the Airborne Imaging Spectrometer for Applications, will allow this technique to be used in an automated operational program at lower cost compared to the AVIRIS imagery.

\section{Literature Cited}

Adams, J.B., D.E. Sabot, V. Kapos, R. Almeida Filho, D.A. Roberts, M.O. Smith, and A.R. Gillespie. 1995. Classification of multispectral images based on fractions of endmembers: application to land cover change in the Brazilian Amazon. Remote Sens. Environ. 52:137-154.

Anderson, G.L., C.W. Prosser, S. Hagar, and B. Foster. 1999. Change detection of leafy spurge infestations using aerial photography and geographic information systems, p. 223-230. Proc. $17^{\text {th }}$ Biennial Workshop Color Aerial Photography and Videography in Resource Assessment. Amer. Soc. of Photogrammetry and Remote Sens., Bethesda, Md.

Anderson, G.L., E.S. Delfosse, N.R. Spencer, C.W. Prosser, and R.D. Richard. 2003. Lessons in developing successful invasive weed control programs. J. Range Manage. 56:2-12.

Boardman, J.W. 1998. Leveraging the high dimensionality of AVIRIS data for improved sub-pixel target unmixing and rejection of false positives: mixture tuned matched filtering. Summaries of the Seventh JPL Airborne Geoscience Workshop. JPL Publication 971:55-56. NASA Jet Propulsion Lab., Pasadena, Calif.

Boardman, J.W., F. A. Kruse, and R. O. Green. 1995. Mapping target signatures via partial unmixing of AVIRIS data. Summaries of the Fifth JPL Airborne Geoscience Workshop, JPL Publication 95-1:23-26. NASA Jet Propulsion Lab., Pasadena, Calif.

Clark, R.N., T.V.V. King, C. Ager, and G.A. Swayze. 1995. Initial vegetation species and senescence/stress mapping in the San Luis Valley, Colorado using imaging spectrometer data. p. 64-69. In H.H. Posey, J.A. Pendelton, and D. Van Zyl (ed) Proc. Summitville Forum '95, Colorado Geol. Surv. Spec. Publ. 38, Denver, Colo.

Congalton, R.G. and K. Green. 1999. Assessing the Accuracy of Remotely Sensed Data: Principles and Practices. Lewis Publishers, Boca Raton, Fla.

Everitt, J.H., D.E. Escobar, and M.R. Davis. 2001. Reflectance and image characteristics of selected noxious rangeland species. J. Range Manage. 54:A106-A1 20.
Everitt, J.H., G.L. Anderson, D.E. Escobar, M.R. Davis, N.R., Spencer, and R.J. Andrascik. 1995. Use of remote sensing for detecting and mapping leafy spurge (Euphorbia esula). Weed Technol. 9:599-609.

Hall, D.K., J.L. Foster, D.L. Verbyla, A.G. Klein, and C.S. Benson. 1998. Assessment of snow-cover mapping accuracy in a variety of vegetation-cover densities in central Alaska. Remote Sens. Environ. 66:129-137.

Harsanyi, J.C. and C. Chang. 1994. Hyperspectral image classification and dimensionality reduction: an orthogonal subspace projection approach. IEEE Trans. Geosci. Remote Sens. 32:779-785.

Hunt, E.R., Jr., J.H. Everitt, J.C. Ritchie, M.S. Moran, D.T. Booth, and G.L. Anderson. 2003. Applications and research using remote sensing for rangeland management. Photogramm. Eng. Remote Sens. 69:675-693.

Gao, B.-C., K.B. Heidebrecht, and A.F.H. Goetz. 1993. Derivation of scaled surface reflectances from AVIRIS data. Remote Sens. Environ. 44:145-163.

Gao, B.-C., K.B. Heidebrecht, and A.F.H. Goetz. 1999. Atmosphere REMoval Program (ATREM) User's Guide, Version 3.1. Center for the Study of Earth from Space (CSES), Cooperative Institute for Research in Environmental Sciences (CIRES), Univ. of Colorado, Boulder, Colo.

Green, R.O., M.L. Eastwood, and 0 . Williams. 1998. Imaging spectroscopy and the Airborne Visible/Infrared Imaging Spectrometer (AVIRIS). Remote Sens. Environ. 65:227-248.

Janssen, L.L.F. and F.J.M. van der Wel. 1994. Accuracy assessment of satellite derived land-cover data: a review. Photogramm. Eng. Remote Sens. 60:419-426.

Jensen, J. R. 1996. Introductory Digital Image Processing: A Remote Sensing Perspective. Prentice Hall, Upper Saddle River, N.J.

Johnson, D.E. 1999. Surveying, mapping, and monitoring noxious weeds on rangelands, $p$. 19-35. In: R.L Sheley and J. K. Petroff (ed.) Biology and Management of Noxious Rangeland Weeds. Oregon State Univ. Press, Corvallis, Ore.

Lajeuness, S., R. Sheley, C. Duncan, and R. Lym. 1999. Leafy spurge. p. 249-260. In: R.L Sheley and J. K. Petroff (ed.) Biology and Management of Noxious Rangeland Weeds. Oregon State Univ. Press, Corvallis, Ore.

Leitch, J.A., F.L. Leistritz, and D.A. Bangsund. 1996. Economic effect of leafy spurge in the Upper Great Plains: Methods, models, and results. Impact Assessment $14: 419-433$.
Marsh, S.E., J.L. Walsh, and C. Sobrevila. 1994. Evaluation of airborne video data for land-cover classification accuracy assessment in an isolated Brazilian forest. Remote Sens. Environ. 48:61-69.

McGwire, K., T. Minor, and L. Fenstermaker. 2000. Hyperspectral mixture modeling for quantifying sparse vegetation cover in arid environments. Remote Sens. Environ. 72:360-374.

Parker Williams, A. E. and E. R. Hunt, Jr. 2002. Estimation of leafy spurge cover from hyperspectral imagery using mixture tuned matched filtering. Remote Sens. Environ. 82:446-456.

Roberts, D. A., M. Gardner, R. Church, S. Ustin, G. Scheer, and R.O. Green. 1998. Mapping chaparral in the Santa Monica mountains using multiple endmember spectral mixture models. Remote Sens. Environ. 65:267-279.

RSI. 1999. ENVI, The Environment for Visualizing Images, User's Guide, Version 3.2, Research Systems, Inc., Boulder, Colo.

Smith, M. O., S.L. Ustin, J.B. Adams, and A.R. Gillespie. 1990. Vegetation in deserts: I. A regional measure of abundance from multispectral images. Remote Sens. Environ. 31:1-26.

Stehman, S.V. and R.L. Czaplewski. 1998. Design and analysis for thematic map accuracy assessment: fundamental principles. Remote Sens. Environ. 64:331-344.

Tueller, P.T. 1989. Remote sensing technology for rangeland management applications. J. Range Manage. 42:442-453.

Tueller, P.T. 1995. Remote sensing in the management of rangelands. Ann. Arid Zone 34:191-207

Verbyla, D.L. and T.O. Hammond. 1995. Conservative bias in classification accuracy assessment due to pixel-by-pixel comparison of classified images with reference grids. Int. J. Remote Sens. 16:581-587. 